\title{
AIDS/HIV as (another) Form of Governmentality
}

\section{Ivan Jurica}

PhD candidate at the Academy of Fine Arts and Design in Bratislava, Slovakia; works in the Art Education Department, MUMOK, Vienna, Austria,

(jurica.ivan@gmail.com)

\begin{abstract}
:
The following contribution is a short summary of an artistic research project on AIDS/HIV, which attempt was/is to reopen and to re-articulate the discourse on the virus and the illness from contemporary feminist and post-colonial perspectives. The idea for this project departed from the constantly imposed and in the meantime unbearable confrontation with the immensely powerful charity machine around AIDS/HIV. We conceive it within the capitalist ideology as the bottom line of processes of normalization. To open this agenda means to open an entire system of capitalist Christian mentality, which concerns contexts of visual representation, popular culture, medical industry, history writing, the "Third" and as well as the "Second" World. In the same instance these processes of normalization resulted in establishing a corrupted homo-normativism that re-produces bourgeois mentality of white supremacy and privatized privileges. Therefore we asked what meaning in such a context bears the terminology of emancipation, solidarity and of a life? These theoretical questions demanded a radicalized curatorial gesture: abandoning the classical gallery-display, and as well asked for a collective ideological positioning.

It is necessary to comprehend the virus and the illness as a site of continuing policy of racialization, segregation, homophobia and further capitalist exploitation within the capitalist post-colonial order.
\end{abstract}

Key Words: AIDS/HIV, charity, solidarity, post-colonial order, feminism

The title of this text refers to an artistic research project of the same name, released through 2012-2013 and originally based at the IG Bildende Kunst Gallery in Vienna (12.12.2012 - 22.2.2013), where the outcomes of the research could be presented in the form of an exhibition, as well as of a further discussion of these outcomes, thus shifting and rearticulating the discourse on the virus and the illness within its post-AIDS-crisis relevancy. At first we (myself, together with co-curator and my boyfriend Miltiadis Gerothanasis) must express our deep appreciation of our colleagues and friends who were ready to go with us into this agenda, the same way then people running the IG Bildende Kunst and its Gallery, as with the further research and realization, we had to experience rather general indifference toward AIDS/ HIV, resulting in one primary question: What about AIDS/HIV? Everything around the virus and the illness seems to be manifested and regulated...

But exactly this question implies its very answer.

Part I.

As the bottom line of the project is the annual medial positivist hysteria/terror around the biggest charity event on AIDS/HIV in the world, the Viennese Life Ball, we can start here. It seems as if the topic of the virus and the illness (but just this virus/illness, not the topic of healthcare in general) became, so to speak, seasonable-as a spectacular exotic topic for a brighter normative audience that is acceptable just in the season of big charity events. Charity machinery should be considered a crucial mechanism within the processes of the normalization/capitalization 
of AIDS/HIV. It operates, in these terms, with the notion of a solidarity, obstructing and reproducing racisms, economic interests and post-colonial aspirations. A major part of the Life Ball spectacle is carried by its visual representation, repeating within the current realm the classical Orientalist colonial image with its historical assignment to prove white supremacy within Euro-Atlantic colonial politics. And it is not to be forgotten that in the meantime these visual symbols and connotations are almost the only (popular) images of the current AIDS/HIV-crisis circulating within the Western media. Also due to this, the charity machinery around AIDS/HIV has in the meantime become extremely profitable within the order of a, so to speak, derived/symbolical profit. If we combine it with the aforementioned notion of a solidarity bound on the silence of those affected, we observe a shift/repetition of the colonial past into the post-colonial presence. Additionally, such events are widely perceived as sites of a 'high'-which ultimately means bourgeoisculture, they are highly official events. But this governmental normalization of HIV/AIDS which followed the AIDS crisis of the 1980s did not mean a dissolution of homophobia within capitalist societies; rather, the homosexual scene and representation of hetero-normative conditions, behavior and ... visual representation.

The political agenda and activities of the AIDS movement of the 1980s were being turned into a de-politicized routine and stupid repetition; anyway the notion of a routine might be applied to several contributions within the project (but of course they are not to be reduced solely to this term): from healthcare for those affected as political action within the crisis into the dumb raw routine of state medical centres (Iman Ithram), from a celebration-instead-of-a-mourning as a symbol of resistance toward death within the homophobic racist state into the stupid partying of the narcissistic charity machine (Jurica), from the provocatively painful presence/depiction of the AIDS-affected into the Hollywood stardom of their sterile heterosexual actors (David Kellner). Another routine, connected with historical racisms, processes of racialization and colonialism, focused on AIDS/HIV as a currently additional form of controlling, exploiting and segregating the African continent (Belinda Kazeem) or criminalizing sex-work and women-migrants seeking the life of citizens and security in the EU (Marissa Lôbo). Another focus of the project research was the Eastern European situation (with the exception of the former Soviet states, which might need their own complex research). Despite a rather consistently low number of infected persons in this area before and after 1989, AIDS/HIV introduced for the local power-structures an enormous potential in terms of the execution of homophobic and nationalistic policies (Kateřina Kolářová elaborated on these topics within the socialist ideology and conditions of Czechoslovakia of the 1980s and early 1990s). Despite, or actually because of this, we ask: What does Western capitalism with its colonial history have in common with post-socialist cultures and the globalised neoliberal market? Relations. 25 Years of the Lesbian Group ŠKUC-LL Ljubljana, a documentary film by Marina Gržinić, Aina Šmid, Zvonka T. Šimčič, elaborates from a reversed position the historical conditions, differences and presence of the feminist movement(s) within the Yugoslav and post-Yugoslav space, placing AIDS/HIV into the complexity of the socialist past and the neo-liberal Christian-capitalist presence.

Despite the preliminary use of the term "exhibition", it is clear that the re-articulation and re-formulation of the discourse on AIDS/HIV from the post-colonial and feminist perspective (where the "feminist" became preferred to the one of the "queer") within this project is a matter of its formal realization too. From the beginning we knew we were not interested in exhibiting AIDS/HIV and in these terms adopting a classical gallery display. The central subjects of the research-in/visibility, media representation and ideology/visual regimes-became mediated by two crucial (formal) elements: the construction of a three-dimensional black cube in a white space and a journal collecting contributions of participating artists and theoreticians. These two elements, both visibly placed in the space of the gallery, complemented each other formally and theoretically. The black cube, with the possibility of being entered, was conceived as a multilayered spatial metaphor: of a darkroom (for (homo)sexual practices), of exclusion and invisibility, as well as of a reference to Kazimir Malevich's Black Square on White, that is, amongst others, further visual reference to questions of symbols, iconography and their readings being framed by an ideology. Which images of AIDS/HIV do we who live in Western globalized cultures know in this context? Why do we know exactly these images, or respectively, what meaning and what role do they fulfil within these cultures?

In these regards I would like to mention the third part carrying the project, a series of film-screenings, and I would like to write in these terms rather about what we didn't and couldn't get, watch, see, get to know, etc. Working on the selection of films we were, within the context of the project and its research, very interested in introducing critical positions different to that of the usual conflictless emotionalized boredom. In this short time of our research, but still taking several months into account and depending on the usual sources of internet, libraries and archives, with the exception of Rosa von Praunheim's AIDS-Trilogy detected in a private collection and still recorded on an old VHS-tape, we couldn't find any work, be it "independent" cinema, older or later documentaries, home-made videos, YouTube etc., that did not fulfil the usual scenario, dramaturgy and ideology of a melodrama. In these entire months we managed to find one single movie on AIDS/HIV made in (South) Africa, directed by a German director and produced with European 
capital, and additionally, once again, embracing all the visual narrative aspects mentioned above. If, within the realm of AIDS/HIV, the binary with Africa or with the "Third World" conceives a basis of its racialization ${ }^{1}$ in the post-colonial global order, then the condition for white solidarity lays in these terms in the colonial silence of the Other, thus copying the old concept of white supremacy. It is not clear yet what form further research will demand, but in the future we would like, returning to the context of a Life Ball, to operate rather with the more appropriate term of a Bare Life Ball.

\section{Addendum}

How these abovementioned practices are being transferred into, so to speak, the everyday rituals of a typical white EU-citizen, is possible to demonstrate with the following few sentences extracted from a talk between two fags from Eastern Europe, based in one of the gay-sex-centres in Amsterdam, ${ }^{2}$ working for one of those multinational companies superintending deterritorialized capital but actually working and comprehending "life" within the realm of virtual space: G: "But you don't forget that in August we have to go to Balaton to this music-festival?" L: "No." G: "I am just reminding you as you actually meant that now after Israel you might run out of money.. " L: "Yes I thought about it." G: "But you want to go.. " L: "I know, I would have to work hard for the next weeks and earn over a hundred and fifty thousand, as then we receive commission rated over five percent. It will be crazy, but it's manageable. It is!" G: "So still we can plan Morocco we wanted do in September? "The guys were continuing the talk about the usual stuff, regularly sipping on cafe latte while checking out the cocks of Israeli and Arab men on their i-pods and i-pads.

Ivan Jurica artist and art-educator, works at intersection of art and politics, focusing history-writing and ideological conditions of art-production, including the East-West relations. Graduated from the Academy of Fine Arts in Vienna in 2009; since then involved in several individual and collective projects. Currently doctoral candidate at the Academy of Fine Arts and Design in Bratislava, elaborating on historical processes of (self)colonization within the post-socialist cultures. Jurica is also active at the art-education department in mumok, Vienna. Lives and works in Vienna and Bratislava.

\footnotetext{
$\overline{1}$ "Racialization" is a term used by Argentinian semiotician Walter Mignolo, describing historical processes of devaluation (first of non-Western people, religions and knowledge) "under the progressive and never ending face of economic growth and capital accumulation". (Mignolo, Walter, "Dispensable and Bare Lives, Coloniality and the Hidden Political/Economic Agenda of Modernity," in Human Architecture: Journal of the Sociology of Self-Knowledge, VII, 2 (Ahead Publishing House), 2009, 71-76.

2 Despite the experience of Amsterdam as a normative post-colonial proto-fascist (Šefik Šeki-Tatlić) space, it was possible to experience, even though on a minimal scale, the opposite: we were invited to present the project within the Queeristan festival, attempting to intervene the later homo-normativism and racisms within Dutch society, organized mainly by young lesbians.
} 
